\title{
Brown frog breeding phenology in south Sweden 1990 - 2017: are data subsets robust?
}

\author{
JON LOMAN
}

\author{
Department of Biology, Lund University, Lund, Sweden \\ Email: jon.loman@biol.lu.se, jon@rana.se
}

\begin{abstract}
Field data on breeding phenology of Rana arvalis and R. temporaria for the period 1990- 2017 in Scania, Sweden are presented and analysed. There was no temporal trend for $R$. temporaria. For $R$. arvalis the results were mixed, one out of two approaches found a trend to earlier breeding. The lack of a consistent trend in breeding phenology is unsurprising considering that local mean air temperatures in February, March and April showed no significant trends over the study period. To test the robustness of the conclusion, different subsets of the data (years or ponds) were also analysed for trends. For most subsets the conclusions remained the same. Possible bias arising from the choice of which years to include in an analysis of trends is discussed.
\end{abstract}

\section{INTRODUCTION}

P henology, especially the progress of spring, has always fascinated people. Arrival of migrating birds (Ekström, 1826), flowering of early plants (Lappalainen, Linkosalo \& Venäläinen, 2008) and also the breeding of frogs, for which Terhivuo (1988a) has compiled data collected since 1846, are examples. Spring breeding frogs in temperate areas are particularly suited for such studies (Richter-Boix et al., 2006). Different signs have been used to record the start of spring activities; breeding migration (Gittins et al., 1980; Reading, 1998; Miwa, 2007; Todd et al., 2011; Arnfield et al., 2012; Klaus \& Lougheed, 2013; Green, 2017), first calling (Strömberg, 1988; Elmberg, 1990; Blaustein et al. 2001a; Hartel, 2008; Lappalainen et al., 2008; Scott et al., 2008; Klaus \& Lougheed, 2013; Steen et al., 2013), or time of spawning (Elmberg, 1990; Beebee, 1995; Gollmann et al., 1999; Blaustein et al., 2001a; Tryjanovski et al., 2003; Hartel, 2008; Scott et al., 2008; Carroll et al., 2009; Neveu, 2009; Loman, 2014). Sensibly, the choice of variable depends mainly upon what is more practical with different species. The subject has received fresh attention as global warming has become a major debate (Beebee, 1995; Blaustein et al., 2001; While \& Uller, 2014). Many long-term studies have been compiled over the years and analysed for trends in breeding phenology. These are summarised and discussed below.

The data and analysis in this report are similar to that of Loman ( 2014) but extend the period from 2010 until the end of 2017 but omit an analysis of pond effect on phenology as previous results were clear enough and were also elaborated (including data until 2015) in Loman (2016).

A problem that is seldom addressed with time series studies is that the outcome partly relies on the, usually random, choice of start year and (hopefully) random choice of end year. A possible solution to this problem is suggested. In addition, an analysis of the robustness of the results is included that considers what the outcome might be if only shorter time series were included or only single ponds. This study is based on a large number of ponds. But would the same conclusions have been reached had only one pond been studied? Analysis of data began after the 2017 field season. Results from the 2018 field season are also included in Figure 2 but are not included in the analyses. This decision is discussed in light of data selection and biases.

\section{METHODS}

\section{Field methods}

The breeding of $R$. arvalis and $R$. temporaria was monitored from 1990 to 2017 in south-central Scania, the southernmost province of Sweden (Table 1; Fig. 1). In this period the number of ponds varied (maximum 120 but some with no spawn) and most ponds were monitored over several years, occasionally interrupted by a single year when the focal pond was dry in spring.

Within pond 'breeding sites' were identified. A breeding site consists of spawn clumps separated by no more than $1 \mathrm{~m}$ although usually all clumps at a site were in physical contact. If breeding took place at the same place but was interrupted by at least 6 days of non-breeding (very rare) this was considered to be two 'breeding sites'. Most ponds had only one or two breeding sites but the number was in some cases much larger. For $R$. arvalis the number of breeding sites per pond ranged from 1 to 17 , with a median of 2.5 and for $R$. temporaria the corresponding numbers were 1 to 15 and 1.9. For each site and species the first date of breeding was recorded. This date usually was a good approximation of the time of breeding for all frogs at the site because at any one site most frogs bred in the first two days (pers. obs.; Loman \& Håkansson, 2004). The ponds were visited at least every 5 days during the breeding period, often more frequently. Time for the earliest spawn at a site could therefore be extrapolated from the condition of the spawn at the time of visits, taking the effect of water temperature on development 
Table 1. Number of ponds monitored. Only ponds where spawn was found are included. Ponds listed under 'Both' are a subset of those listed under either species.

\begin{tabular}{|c|c|c|c|c|}
\hline & R. arvalis & R. temporaria & Both & $\begin{array}{l}\text { Ponds with } \\
\text { spawn }\end{array}$ \\
\hline 1990 & 8 & 25 & 7 & 26 \\
\hline 1991 & 7 & 27 & 6 & 28 \\
\hline 1992 & 8 & 30 & 8 & 30 \\
\hline 1993 & 10 & 28 & 8 & 30 \\
\hline 1994 & 25 & 65 & 24 & 66 \\
\hline 1995 & 26 & 60 & 18 & 68 \\
\hline 1996 & 28 & 70 & 28 & 70 \\
\hline 1997 & 32 & 79 & 30 & 81 \\
\hline 1998 & 43 & 80 & 38 & 85 \\
\hline 1999 & 40 & 86 & 40 & 86 \\
\hline 2000 & 42 & 83 & 38 & 87 \\
\hline 2001 & 46 & 81 & 39 & 88 \\
\hline 2002 & 44 & 82 & 39 & 87 \\
\hline 2003 & 34 & 69 & 29 & 74 \\
\hline 2004 & 42 & 71 & 33 & 80 \\
\hline 2005 & 47 & 76 & 41 & 82 \\
\hline 2006 & 20 & 40 & 19 & 41 \\
\hline 2007 & 26 & 47 & 25 & 48 \\
\hline 2008 & 23 & 45 & 23 & 45 \\
\hline 2009 & 7 & 29 & 6 & 30 \\
\hline 2010 & 10 & 31 & 10 & 31 \\
\hline 2011 & 13 & 31 & 12 & 32 \\
\hline 2012 & 13 & 30 & 13 & 30 \\
\hline 2013 & 10 & 26 & 9 & 27 \\
\hline 2014 & 7 & 25 & 6 & 26 \\
\hline 2015 & 9 & 28 & 9 & 28 \\
\hline 2016 & 4 & 7 & 4 & 7 \\
\hline 2017 & 3 & 4 & 3 & 4 \\
\hline
\end{tabular}

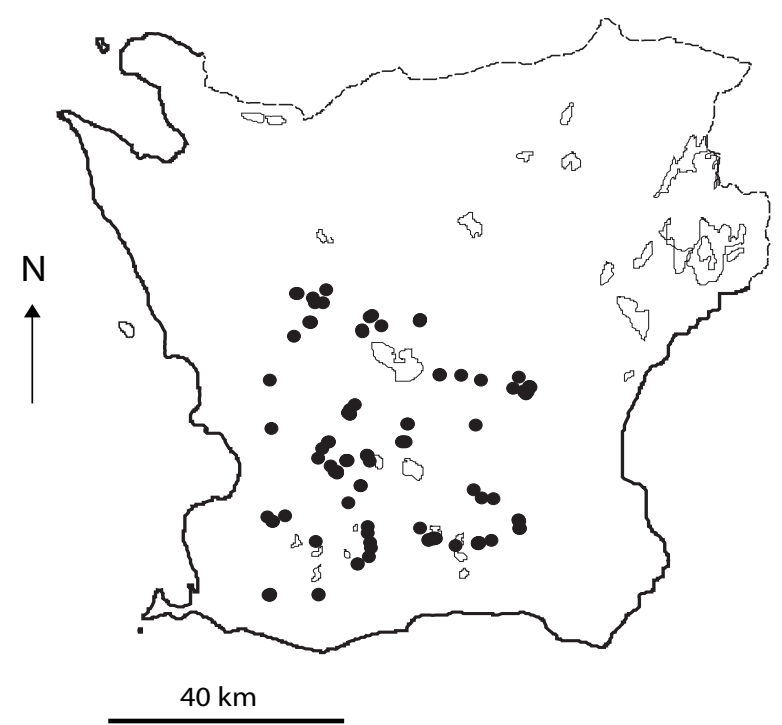

Figure 1. Map of study ponds in the province Scania, south Sweden. Lakes are outlined for easier orientation. into account. This can usually be done with a certainty of one or at most two days. A similar approach was adopted by Tryjanowski et al. (2003). Frequent visits, observing fresh spawn, also made it easier to separate the spawn of the two species. After a few days this tends to be difficult. The number of spawn clumps at each breeding site was counted or estimated from the area of the egg mass at the breeding site (Loman \& Andersson, 2007).

\section{Analysis of trends}

For each pond, breeding time was computed as the average breeding time for all sites in the pond, weighted by the number of female frogs breeding (assumed equal to number of spawn clumps) at each site. Thus the measure approximated to the actual average breeding time for all frogs at each pond. This use of breeding sites in the present context explains why a breeding site was counted as 'new' after 6 days of interrupted breeding (a rare occurrence).

For each year, breeding time was calculated as the average time for all ponds studied in that year (raw means). This suffered from the fact that different ponds were studied in different years. To account for this an alternative measure of yearly breeding time was also used. The ponds were subject to an ANOVA (with ponds and year as categories). Data was weighted by number of frogs breeding at a pond and the least square mean was used to represent each year. Trends were analysed as the correlation between year and breeding time. For an alternative approach, the combined effect of pond and year on breeding time was also analysed as an ANCOVA.

\section{Subset analysis}

Trend analyses depend much on the starting year. If data collection starts in a year with late breeding there is a bias for a negative trend (earlier breeding in later years), and vice versa. Analyses were therefore done for subsets of the complete data set, assuming data collection had started in 1991 (rather than 1990), 1992, 1993 etc. The shortest data set analysed used 5 years of data, starting in 2013. Subsets based on single ponds were also analysed. Trends for all ponds monitored for at least 20 years and starting no later than 1995 were therefore also analysed.

\section{RESULTS}

\section{Trends?}

There was no significant trend in the time for breeding for either species (Fig. 2). This was true both using raw year means (Both $\mathrm{n}=28$ : $R$. arvalis: $r=-0.28, \mathrm{p}=0.16 ; R$. temporaria: $r=-0.18, \mathrm{p}=0.37$ ) and least squares means (Both $\mathrm{n}=28: R$. arvalis: $r=-0.25, \mathrm{p}=0.20 ; R$. temporaria: $r=-0.07, \mathrm{p}=0.72$ ) as a measure of the start to breeding. For both species there were non-significant negative slopes. Although the slope was steeper for $R$. arvalis there was no significant difference between the species (ANCOVA, Year*Species interaction; Raw means: d.f. $=1: 52, F=0.14, p=0.71$; Least squares means: d.f. $=1: 52, F=0.46, p=0.50)$.

The ANCOVA found no interaction between pond and time (year) on breeding date for either species ( $R$. arvalis: d.f. $=16: 199, F=1.32, p=0.19 ; R$. temporaria: d.f. $=42: 577$, 


\section{Rana arvalis}

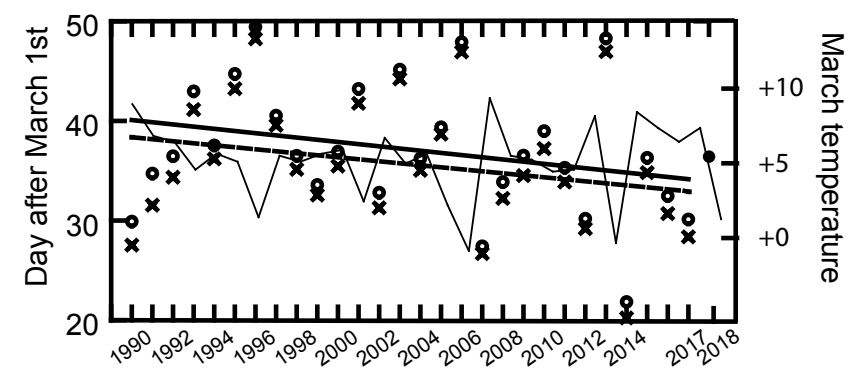

Rana temporaria

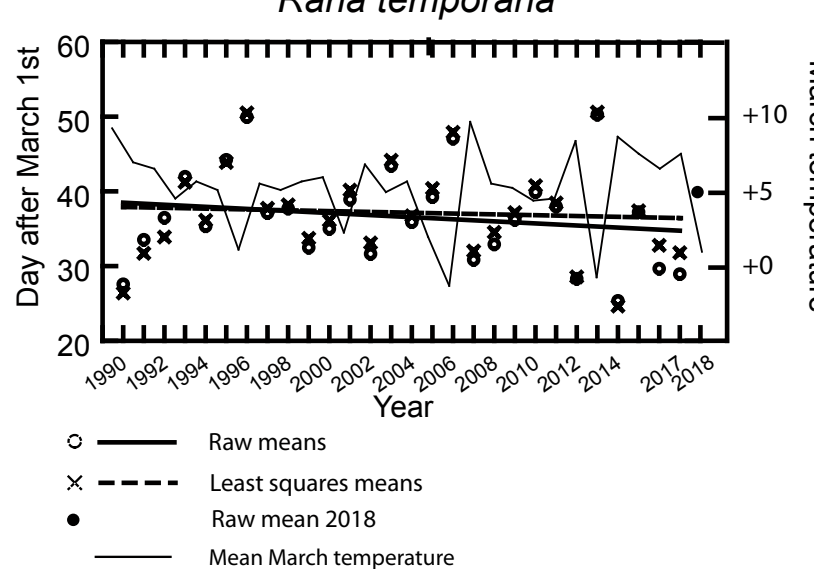

Figure 2. Mean breeding date and linear trends for years 1990 to 2017. The computation of the two types of yearly mean is explained in the Methods. Data for 2018 are not included in the regression lines.

$F=1.36, p=0.07)$. However removing the interactions, both pond and time (year) had a significant effect on breeding date in $R$. arvalis (Pond: d.f. $=16: 215, F=2.52$, $p<0.001$; Year: d.f. $=1: 215, F=7.61, p=0.006)$. For $R$. temporaria only pond but not year had a significant effect on breeding date (Pond: d.f. $=42: 619, F=3.46, p<0.001$; Year: d.f. $=1: 619, F=1.53$, $\mathrm{p}=0.217)$.

\section{Temperature effects}

Among years, the trend in phenology for both species were negatively correlated to February, March and (almost so to) April temperatures $(\mathrm{n}=28 ; R$. arvalis: $r=0.43, \mathrm{p}=0.02, r=0.84$, $p<0.001, r=0.48, p=0.11 ; R$. temporaria: $r=0.46, p=0.016$, $r=0.85, p<0.001, r=0.35, p=0.07$ respectively), with earlier breeding in warmer years. During the study period 1990 to 2017 there were no trends in spring (February, March or April) temperatures (all $\mathrm{n}=28: r=0.14 \mathrm{p}=0.48 ; r=0.01, \mathrm{p}=0.94$; $r=0.15, p=0.43$, respectively) in the study region.

\section{Subsets}

Had the data collection started in any of the years 1992, 1993, 1994 or 1995 (rather than in 1990, analyzed above) one would have found a significant negative trend $(p<0.05)$ for the breeding start of $R$. arvalis (Table 2). For these years the negative trend was almost significant for $R$. temporaria ( $p=0.05-0.10)$. Had the study started in 1996 or later, the conclusions were the same as for the present study; with no significant trend for either species.

The results from the ANCOVA for successive subsets of years are similar (Table 3 ). If the analysis started from any of
Table 2. Tests for significance of trends in phenology, using alternative starting year. All sequences end with 2017. Trends are based on raw pond breeding dates within years.

\begin{tabular}{|c|c|c|c|c|c|c|}
\hline & \multicolumn{3}{|c|}{ R. arvalis } & \multicolumn{3}{|c|}{ R. temporaria } \\
\hline & $\mathrm{n}$ & $r$ & $p$ & $\mathrm{n}$ & $r$ & p \\
\hline 1990 - 2017 & 28 & -0.28 & 0.16 & 28 & -0.17 & 0.37 \\
\hline $1991-2017$ & 27 & -0.37 & 0.055 & 27 & -0.29 & 0.14 \\
\hline $1992-2017$ & 26 & -0.42 & 0.03 & 26 & -0.35 & 0.081 \\
\hline $1993-2017$ & 25 & -0.46 & 0.02 & 25 & -0.38 & 0.064 \\
\hline $1994-2017$ & 24 & -0.44 & 0.032 & 24 & -0.35 & 0.095 \\
\hline $1995-2017$ & 23 & -0.46 & 0.026 & 23 & 0.39 & 0.066 \\
\hline $1996-2017$ & 22 & -0.42 & 0.052 & 22 & -0.34 & 0.12 \\
\hline $1997-2017$ & 21 & -0.32 & 0.16 & 21 & -0.21 & 0.36 \\
\hline $1998-2017$ & 20 & -0.29 & 0.22 & 20 & -0.21 & 0.37 \\
\hline $1999-2017$ & 19 & -0.31 & 0.2 & 19 & -0.2 & 0.41 \\
\hline $2000-2017$ & 18 & -0.37 & 0.13 & 18 & -0.28 & 0.27 \\
\hline $2001-2017$ & 17 & -0.4 & 0.12 & 17 & -0.32 & 0.21 \\
\hline $2002-2017$ & 16 & -0.33 & 0.21 & 16 & -0.3 & 0.26 \\
\hline $2003-2017$ & 15 & -0.42 & 0.12 & 15 & -0.41 & 0.12 \\
\hline $2004-2017$ & 14 & -0.32 & 0.26 & 14 & -0.34 & 0.24 \\
\hline $2005-2017$ & 13 & -0.34 & 0.26 & 13 & -0.37 & 0.21 \\
\hline $2006-2017$ & 12 & -0.3 & 0.34 & 12 & -0.35 & 0.26 \\
\hline $2007-2017$ & 11 & -0.06 & 0.86 & 11 & -0.16 & 0.65 \\
\hline $2008-2017$ & 10 & -0.26 & 0.46 & 10 & -0.28 & 0.44 \\
\hline $2009-2017$ & 9 & -0.32 & 0.39 & 9 & -0.38 & 0.31 \\
\hline $2010-2017$ & 8 & -0.32 & 0.44 & 8 & -0.41 & 0.31 \\
\hline $2011-2017$ & 7 & -0.22 & 0.63 & 7 & -0.34 & 0.46 \\
\hline $2012-2017$ & 6 & -0.2 & 0.7 & 6 & -0.27 & 0.6 \\
\hline $2013-2017$ & 5 & -0.42 & 0.48 & 5 & -0.61 & 0.27 \\
\hline
\end{tabular}

Rana arvalis

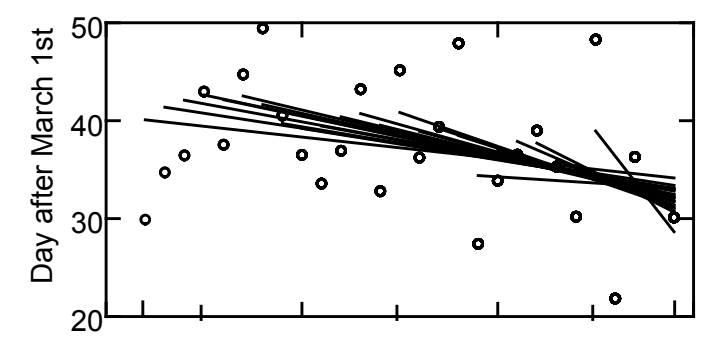

Rana temporaria

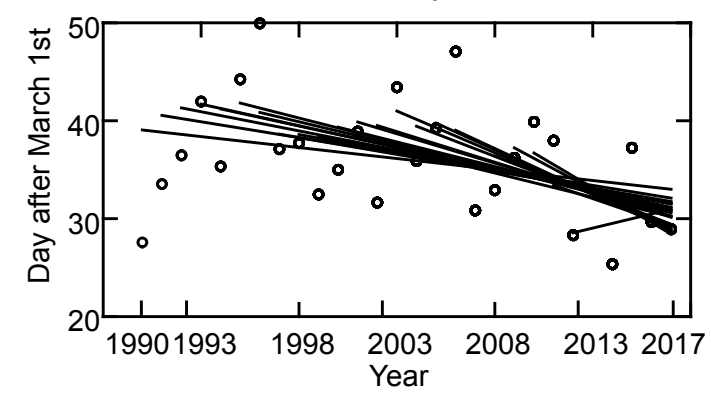

Figure 3. Trends in breeding, based on raw means of breeding date within ponds and years. The starting year for each trend is evident from the left end of each line. The shortest trend analysed was 2013 to 2017 inclusive. 
Table 3. As Table 2 but analysis based on a 2-way ANCOVA; pond and year effects on breeding date. Only year effects are accounted for in the table. All interactions are non-significant and were removed before final analysis.

\begin{tabular}{|c|c|c|c|c|c|c|}
\hline & \multicolumn{3}{|c|}{ R. arvalis } & \multicolumn{3}{|c|}{ R. temporaria } \\
\hline & d.f. & $\boldsymbol{F}$ & $p$ & d.f. & $F$ & $p$ \\
\hline 1990 - 2017 & $1: 227$ & 7.7 & 0.006 & $1: 679$ & 0.92 & 0.34 \\
\hline 1991 - 2017 & $1: 221$ & 15.1 & $<0.001$ & $1: 660$ & 8.59 & 0.004 \\
\hline $1992-2017$ & $1: 216$ & 20.5 & $<0.001$ & 1:639 & 17.7 & $<0.001$ \\
\hline $1993-2017$ & $1: 208$ & 27.7 & $<0.001$ & $1: 613$ & 26.8 & $<0.001$ \\
\hline $1994-2017$ & $1: 200$ & 21.9 & $<0.001$ & 1:591 & 23.8 & $<0.001$ \\
\hline $1995-2017$ & 1:188 & 26.3 & $<0.001$ & 1:553 & 36.1 & $<0.001$ \\
\hline $1996-2017$ & 1:175 & 16 & $<0.001$ & 1:519 & 18.9 & $<0.001$ \\
\hline $1997-2017$ & 1:163 & 5.14 & 0.025 & $1: 485$ & 0.36 & 0.55 \\
\hline 1998 - 2017 & 1:149 & 2.32 & 0.13 & $1: 446$ & 0.17 & 0.68 \\
\hline 1999 - 2017 & 1:134 & 2.75 & 0.1 & $1: 407$ & 0.081 & 0.78 \\
\hline $2000-2017$ & 1:121 & 6.2 & 0.14 & $1: 368$ & 3.22 & 0.073 \\
\hline $2001-2017$ & $1: 108$ & 7.81 & 0.006 & $1: 330$ & 6.66 & 0.01 \\
\hline $2002-2017$ & $1: 94$ & 3.48 & 0.065 & $1: 293$ & 1.66 & 0.199 \\
\hline $2003-2017$ & $1: 78$ & 7.87 & 0.006 & $1: 257$ & 10.6 & 0.001 \\
\hline $2004-2017$ & $1: 66$ & 2.35 & 0.13 & $1: 225$ & 2.1 & 0.15 \\
\hline 2005 - 2017 & $1: 52$ & 2.72 & 0.11 & 1:188 & 5.51 & 0.02 \\
\hline $2006-2017$ & $1: 42$ & 0.56 & 0.45 & 1:164 & 2.65 & 0.11 \\
\hline $2007-2017$ & 1:35 & 1.68 & 0.2 & 1:145 & 1.42 & 0.23 \\
\hline 2008 - 2017* & & & & 1:121 & 0.17 & 0.68 \\
\hline 2009 - 2017 & $1: 20$ & 0.58 & 0.46 & 1:102 & 1.21 & 0.27 \\
\hline $2010-2017$ & 1:18 & 0.53 & 0.48 & $1: 85$ & 2.63 & 0.11 \\
\hline $2011-2017$ & 1:15 & 0.13 & 0.72 & $1: 68$ & 0.53 & 0.47 \\
\hline 2012 - 2017 & $1: 11$ & 0.048 & 0.83 & $1: 52$ & 0.051 & 0.82 \\
\hline $2013-2017$ & $1: 7$ & 1.6 & 0.25 & 1:36 & 9.73 & 0.004 \\
\hline $2014-2017$ & 1:4 & 1.68 & 0.26 & $1: 22$ & 3.46 & 0.076 \\
\hline
\end{tabular}

the years 1990 to 1996 then there was a significant effect of YEAR (with earlier breeding in later years) for $R$. arvalis (Fig. $3)$. For $R$. temporaria this was only true for the series starting from 1991 to 1996. For shorter time series (starting later than 1997 or 1996 respectively), usually no year effect could be detected. An exception (for both species) was starting in 2003, a year in which breeding started very late, when a year effect was found.

A study was also made to investigate what conclusions would be reached if only one pond was sampled. For this analysis it is assumed that the study started in 1993. This choice is motivated by the fact that this starting year yielded 'the most significant' result $(\mathrm{p}<0.02)$ for $R$. arvalis and was almost significant $(p=0.064$ ) for $R$. temporaria (Table 2 ). This analysis included all ponds for which monitored starting no later than 1995 and continued until at least 2015. For only one of these 20 ponds there was a trend to earlier breeding (R. arvalis: $\mathrm{n}=23, r=-0.53, \mathrm{p}=0.009$, all others ponds $\mathrm{p}>0.11 ; R$. temporaria: $\mathrm{n}=23, r=-0.44, \mathrm{p}=0.035$, all other ponds $p>0.08$ ). The fact that the ANCOVA test never found any interactions between pond and year confirms that the conclusions are robust with respect to the choice of ponds.

\section{DISCUSSION}

\section{Trends}

In the previous analysis of this data set up to 2010, a significant trend to earlier breeding could not be detected with certainty. Adding another 7 years of data has allowed a more powerful and/or reliable analysis. The more simplistic analyses still do not find any trends towards earlier breeding, using the full data set. However, taking advantage of the large number of ponds included in the study and with pond identity included in the analysis, accounting for possible concordance among pond trends (by means of an ANCOVA), there is a significant trend to earlier breeding for $R$. arvalis. However, not even this approach finds any trend in breeding phenology in $R$. temporaria. The weak trends come as no surprise as there were no trends in spring temperatures during the study period.

\section{Causes for lack of trends}

Several other studies have documented trends to earlier breeding in frogs but there are also exceptions (Table 4). If no trend is found, it could simply mean that there has been no climate trend in the study area. This seems to be the explanation in the present case. Actually, one of the main lessons from this study is that climate trends are geographically very heterogeneous, and one should not automatically assume everything is happening earlier in all areas! Another reason could be that the organisms are date conservative, date is as important a clue to phenology as short term weather, as shown by Harri \& Koskela (1997) in a common garden study of $R$. temporaria. There are two reasons. Although early breeding is the key to a head start for the offspring, eventually resulting in a larger size of young frogs at the time of first hibernation, the effect is not as strong as one might suspect; a few days difference in egg laying and hatching make for even less difference later in the season (Loman, 2009, Steen et al., 2013, Benard, 2015). There is also a strong incentive not to respond too strongly to an occasional warm spring as the likelihood of a set back with later low temperatures is not to be neglected (Loman, 2009). The price to pay in these cases is high as the spawn risks destruction by freezing of the breeding pond.

\section{Robustness}

Shortening the study period did not affect the conclusion reached for $R$. temporaria. For $R$. arvalis the outcome was ambiguous. By chance (starting the study one or a few years later) it could have been concluded that there was indeed a trend for earlier breeding. The large number of years for this study gave an opportunity to put the main conclusion in perspective. Also, studying only one pond had in almost all cases resulted in reaching the same conclusion. Again, the large number of ponds studied gave an opportunity to test the robustness of the conclusions in this respect.

There are two reasons for not redoing the analyses after the 2018 field season. First, it had meant more work and sometimes you have to decide that something is finished, no more data collection and time to start compilation. This decision should be (and was) taken regardless of the last data point (2017) being late or early. Second, 2018 was a late year 
Table 4. Results from long-term studies of frog phenology

\begin{tabular}{|c|c|c|c|c|c|}
\hline Species & Site & Measure & Time span & Trend & Ref. \\
\hline R. temporaria & Finland & Spawn & $1846-1986$ & Earlier & Terhivuo, 1988a, Terhivuo, 1988b \\
\hline B. bufo & S England & Migration & $1980-1998$ & No trend & Reading, 1998 \\
\hline $\begin{array}{l}\text { Rana cascadae (site } 1 \\
\text { and } 2 \text { ) }\end{array}$ & Oregon, USA & Spawn & $1982-1999$ & No trend & Blaustein et al., 2001 \\
\hline $\begin{array}{l}\text { Bufo boreas } \\
\text { (site 1) }\end{array}$ & Oregon, USA & Spawn & 1982 - 1999 & Dubious earlier & Blaustein et al., 2001 \\
\hline $\begin{array}{l}\text { Bufo boreas } \\
\text { (site } 2 \text { and } 3 \text { ) }\end{array}$ & Oregon, USA & Spawn & 1982 - 1999 & No trend & Blaustein et al., 2001 \\
\hline Pseudacris crucifer & Michigan, USA & Call & $1967-1994$ & No trend & Blaustein et al., 2001 \\
\hline Bufo fowleri & Oregon, USA & Call & $1980-1998$ & No trend & Blaustein et al., 2001 \\
\hline Pseudacris crucifer & New York, USA & Call & $\begin{array}{l}1900-1912 \text { comp. } \\
\text { to } 1990-1999\end{array}$ & Early trend & Gibbs \& Breisch, 2001 \\
\hline Rana sylvatica & New York, USA & Call & $\begin{array}{l}1900-1912 \text { comp. } \\
\text { to } 1990-1999\end{array}$ & Early trend & Gibbs \& Breisch, 2001 \\
\hline Rana catesbeiana & New York, USA & Call & $\begin{array}{l}1900-1912 \text { comp. } \\
\text { to } 1990-1999\end{array}$ & $\begin{array}{l}\text { Possibly early } \\
\text { trend }\end{array}$ & Gibbs \& Breisch, 2001 \\
\hline Hyla versicolor & New York, USA & Call & $\begin{array}{l}1900-1912 \text { comp. } \\
\text { to } 1990-1999\end{array}$ & Early trend & Gibbs \& Breisch, 2001 \\
\hline Bufo americanus & New York, USA & Call & $\begin{array}{l}1900-1912 \text { comp. } \\
\text { to } 1990-1999\end{array}$ & No trend & Gibbs \& Breisch, 2001 \\
\hline Rana clamitans & New York, USA & Call & $\begin{array}{l}1900-1912 \text { comp. } \\
\text { to } 1990-1999\end{array}$ & No trend & Gibbs \& Breisch, 2001 \\
\hline R. temporaria & Poland & Spawn & $1978-2002$ & Earlier & Tryanowski, Rybacki \& Sparks, 2003 \\
\hline Bufo bufo & Poland & Spawn & $1978-2002$ & Earlier & Tryanowski, Rybacki \& Sparks, 2003 \\
\hline R. temporaria & Central Finland & Call & $1952-2005$ & Earlier & $\begin{array}{l}\text { Lappalainen, Linkosalo \& Venäläinen, } \\
2008\end{array}$ \\
\hline Rana temporaria & Eastern England & Spawn & $1978-2005$ & Weak early trend & Sparks et al. 2007 \\
\hline Rana temporaria & Wales & Spawn & $1978-2005$ & No trend & Sparks et al., 2007 \\
\hline Bufo bufo & Eastern England & Migration & $1978-2005$ & Early spawning & Sparks et al., 2007 \\
\hline Rana ornativentris & Tokyo, Japan & Spawning & $1992-2007$ & Earlier & Kusano \& Inouse, 2008 \\
\hline Rhacophorus arboreus & Tokyo, Japan & Spawning & $1992-2007$ & Earlier & Kusano \& Inouse, 2008 \\
\hline R. temporaria & United Kingdom & Hatching & $\begin{array}{l}\text { Starting 1994-99, } \\
\text { lasting 5-12 y. }\end{array}$ & No trend & Scott, Pithart \& Adamson, 2008 \\
\hline R. temporaria & United Kingdom & Spawning & $\begin{array}{l}\text { Starting 1994-99, } \\
\text { lasting 5-12 y. }\end{array}$ & Earlier & Scott, Pithart \& Adamson, 2008 \\
\hline R. temporaria & NW France & Spawn & $1984-2007$ & Earlier & Neveu, 2009 \\
\hline Bufo americanus & Ontario & Call & $1970-2010$ & Earlier & Klaus \& Lougheed, 2013 \\
\hline Rana pipiens & Ontario & Call & $1970-2010$ & Earlier & Klaus \& Lougheed, 2013 \\
\hline Rana sylvatica & Ontario & Call & $1970-2010$ & Dubious earlier & Klaus \& Lougheed, 2013 \\
\hline Hyla versicolor, & Ontario & Call & $1970-2010$ & No trend & Klaus \& Lougheed, 2013 \\
\hline Pseudacris crucifer, & Ontario & Call & $1970-2010$ & No trend & Klaus \& Lougheed, 2013 \\
\hline Rana catesbeiana & Ontario & Call & $1970-2010$ & No trend & Klaus \& Lougheed, 2013 \\
\hline R. arvalis & South Sweden & Spawn & $1990-2010$ & Dubious earlier & Loman, 2014 \\
\hline R. temporaria & South Sweden & Spawn & $1990-2010$ & No trend & Loman, 2014 \\
\hline
\end{tabular}

and thus supports the main conclusion; there is no or a very weak trend to earlier breeding for these species in this region. Adding the 2018 data, knowing the outcome of the season, could justifiably be considered a bad statistical practice. But it is worthwhile to present the data (Fig. 2) and point out that this season certainly does not weaken the conclusion!

\section{ACKNOWLEDGEMENTS}

The field work has been supported by the Swedish council for Forestry and Agricultural Research (1990-94) and the Skåne Regional Authorities (1995-2005). Gunilla Andersson, Björn Lardner, Ingegärd Ljungblom, Jonatan Loman, Torkel Loman, Gunilla Lundh, Elsa Månsson, Håkan Sandsten, Herman van Steenwijk and Ralph Tramontano have all helped in the 
field. Thanks also to Björn Lardner who made great efforts to improve the text. Comments by Trevor Beebee and an anonymous reviewer also improved the manuscript.

\section{REFERENCES}

Arnfield, H., Grant, R., Monk, C. \& Uller, T. (2012). Factors influencing the timing of spring migration in common toads (Bufo bufo). Journal of Zoology 288: 112-118.

Beebee, T.J.C. (1995). Amphibian breeding and climate. Nature 374: 219-220.

Benard, M.F. (2015). Warmer winters reduce frog fecundity and shift breeding phenology, which consequently alters larval development and metamorphic timing. Global Change Biology 21: 1058-1065.

Blaustein, A.R., Belden, L.K., Olson, D.H., Root, T.L. \& Kiesecke, J.M. (2001). Amphibian breeding and climate change. Conservation Biology 15: 1804-1809.

Blaustein, A.R., Root, T.L., Kiesecker, J.M., Belden, L.K., Olson, D.H. \& Green, D.M. (2003). Amphibian breeding and climate change: Reply to Corn. Conservation Biology 17: 626-627.

Carroll, E.A., Sparks, T.H., Collinson, N. \& Beebee, T.J.C. (2009). Influence of temperature on the spatial distribution of first spawning dates of the common frog (Rana temporaria) in the UK. Global Change Biology 15: 467-473.

Ekström, C.U. (1826). Strödda anteckningar om svenska flyttfoglarna, och i synnerhet tiden för deras ankomst och afflyttning i Södermanland. Kungliga Vetenskapsakademins Handlingar.

Elmberg, J. (1990). Long-term survival, length of breeding season, and operational sex ratio in a boreal population of common frogs, Rana temporaria L. Canadian Journal of Zoology 68: 121-127.

Gibbs, J.P. \& Breisch, A.R. (2001). Climate warming and calling phenology of frogs near Ithaca, New York, 19001999. Conservation Biology 15: 1175-1178.

Gittins, S.P., Parker, A.G. \& Slater, F.M. (1980). Population characteristics of the common toad (Bufo bufo) visiting a breeding site in Mid-Wales. Journal of Animal Ecology 49: 161-173.

Gollmann, G., Baumgartner, C., Gollmann, B. \& WaringerLöschenkohl, A. (1999). Breeding phenology of syntopic frog populations, Rana dalmatina and Rana temporaria, in suburban Vienna. Verhandlungen der Gesellschaft für Ökologie 29: 357-361.

Green, D.M. (2017). Amphibian breeding phenology trends under climate change: predicting the past to forecast the future. Global Change Biology 23: 646-656.

Harri, M.N. \& Koskela, P. (1977). Terms of spawning in southern and northern Finnish populations of the common frog, Rana temporaria L. under laboratory conditions. Aquilo Ser Zoology 17: 49-51.

Hartel, T. (2008). Weather conditions, breeding date and population fluctuations in Rana dalmatina from central Romania. Herpetological Journal 18: 40-44.

Klaus, S.P. \& Lougheed, S.C. (2013). Changes in breeding phenology of eastern Ontario frogs over four decades. Ecology and Evolution 3: 835-845.

Kusano, T. \& Inoue, M. (2008). Long-term trends toward earlier breeding of Japanese amphibians. Journal of Zoology 42: 608-614.
Lappalainen, H.K., Linkosalo, T. \& Venäläinen, A. (2008). Long-term trends in spring phenology in a boreal forest in central Finland. Boreal Environmental Research 13: 303-318.

Loman, J. (2009). Primary and secondary phenology. Does it pay a frog to breed early? Journal of Zoology 279: 64-70.

Loman, J. (2014). (Almost) no trend in brown frog (Rana arvalis and $R$. temporaria) breeding phenology in southern Sweden 1990 - 2010. Alytes 30: 4-10.

Loman, J. (2016). Breeding phenology in Rana temporaria. Local variation is due to pond temperature and population size. Ecology and Evolution 6: 6202-6209.

Loman, J. \& Andersson, G. (2007). Monitoring brown frogs Rana arvalis and $R$. temporaria in 120 south Swedish ponds 1989 - 2005. Mixed trends in different habitats. Biological Conservation 135: 46-56.

Loman, J. \& Håkansson, P. (2004). Communal spawning in the common frog Rana temporaria - egg temperature and predation consequences. Ethology 110: 665-680.

Miwa, T. (2007). Conditions controlling the onset of breeding migration of the Japanese mountain stream frog, Rana sakuraii. Naturwissenschaften 94: 551-560.

Neveu, A. (2009). Incidence of climate on common frog breeding: Long-term and short-term changes. Acta Oecologica 35: 671-678.

Reading, C.J. (1998). The effect of winter temperatures on the timing of breeding activity in the common toad Bufo bufo. Oecologia 117: 469-475.

Richter-Boix, A., Llorente, G.A. \& Montori, A. (2006). Breeding phenology of an amphibian community in a Mediterranean area. Ampibia-Reptilia 27: 549-559.

Scott, W.A., Pithart, D. \& Adamson, J.K. (2008). Long-term United Kingdom trends in the breeding phenology of the common frog, Rana temporaria. Journal of Herpetology 42: 89-96.

Sparks, T., Tryjanowski, P., Cookje, A., Crick, H. \& Kuzniak, S. (2007). Vertebrate phenology at similar latitudes: temperature response. Climate Research 34: 93-98.

Steen, D.A., McClure, C.J.W. \& Graham, S.P. (2013). Relative influence of weather and season on anuran calling activity. Canadian Journal of Zoology 91: 462-467.

Strömberg, G. (1988). A study of the jumping frog (Rana dalmatina) in Blekinge, Sweden, 1982-1988. Memoranda Societas Fauna Flora Fennici 64: 107-109.

Terhivuo, J. (1988a). Phenology of spawning for common frog (Rana temporaria L.) in Finland from 1846 to 1986. Annales Zoologici Fennici 25: 165-175.

Terhivuo, J. (1988b). Spawning of the common frog Rana temporaria in Finland during 1846-1986. Memoranda Societas Fauna Flora Fennici 64: 155-157.

Todd, B.D., Scott, D.E., Pechmann, J.H.K. \& Gibbons, J.W. (2011). Climate change correlates with rapid delays and advancements in reproductive timing in an amphibian community. Proceedings of the Royal Society $B$ : Biological Sciences 278: 2191-2197.

Tryjanovski, P., Rybacki, M. \& Sparks, T. (2003). Changes in the first spawning dates of common frogs and common toads in western Poland in 1978-2002. Annales Zoologici Fennici 40: 459-464.

While, G., M. \& Ulle, T. (2014). Quo vadis amphibia? Global warming and breeding phenology in frogs, toads and salamanders. Ecography 37: 921-929.

Accepted: 19 March 2019 